\title{
The Impact of Women Directors on Executive-Staff Pay Dispersion
}

\author{
Qianying Wang ${ }^{1, *}$ and Changzheng Zhang ${ }^{1}$
}

\author{
${ }^{1}$ School of Economics and Management, Xi'an University of Technology, Xi'an, Shaanxi 710054, China \\ *Corresponding author. Email:1217504435@qq.com
}

\begin{abstract}
This paper explores the relationship between the women directors' participation degree and the ESPD by using an unbalanced panel sample, which consists of 1554 firm-year observations collected from 2010-2018 among energy companies listed on the Shenzhen and Shanghai stock exchanges in China. Based on the multiple linear regression analysis methods, the correlation analysis, and the fixed effects regression, the empirical analysis has come to three findings. Firstly, on the whole, women directors have a negative effect on the ESPD. Secondly, the negative effect of women directors on the ESPD has been reduced into a zero effect due to the issue of the Salary Restriction Order, which indicates that there is a significant substitution effect between women directors' salary supervision and the governments' salary regulation. Thirdly, women directors indirectly affect the ESPD by weakening other stakeholders' original attitudes towards the ESPD. The issue of the impact of women directors on ESPD has not been explored to an acceptable extent in the existing literature, and this study fills the gap.

Keywords: women directors, executive-staff pay dispersion (ESPD), human capital theory, principal-agent
\end{abstract}

theory

\section{INTRODUCTION}

According to the research of Zhang et al. (2018), the ratio of CEO to frontline staff compensation in major Chinese listed firms has exceeded 30-to-1, and moreover, the ratio is rapidly getting larger [1]. In this case, the antecedents of the ESPD and its responding effects on improving the ESPD become critical topics for corporate governance research. In addition, such research can be helpful for the firms to set reasonable ESPD, and for the Chinese government to control the unlimited growth of the social income gap derived from the ever-increasing ESPD. A systematic literature review on the compensation research indicates that although many antecedents of the ESPD have been investigated (Hambrick, \&Siegel, 1997; Zhang et al., 2018) [1,2], the role of the women directors' participation on the board in setting the ESPD has not been explored.

As an emerging group of leaders recently, without any doubt, the role of the women directors in the board is attracting more and more attention from management scholars around the world. Despite the objectively large number of women directors who have succeeded in creating the amazing performance and contributions in running modern companies, the leadership effectiveness of the women directors remains controversial among different scholars, especially in China. The role of the women directors in affecting ESPD, a critical process variable, has not been investigated to a good degree by the extant literature. According to the existing theoretical perspective on studying the role of women directors in corporate governance, the women directors would show different attitudes from male directors in most important decisions, which inevitably includes the issue of decision making regarding ESPD. In order to fill this research gap, this paper focuses on the relationship between the women directors' participation degree in the board and the ESPD.

\section{LITERATURE REVIEW AND THE HYPOTHESES}

From the perspective of principal-agent theory, women directors would have a positive impact on ESPD, while from the perspective of human capital theory, women directors would have a negative impact on ESPD. It is difficult to judge which impact will be the dominant one. Therefore, this section would present two opposite competing hypotheses from the two perspectives.

\subsection{The Positive Role of the Women Directors Drawing the Principal-Agent Theory}

The principal-agent theory views senior managers as selfinterest agents who aim to maximize their own interests, while shareholders and the board of directors are principals who act in the interest of the firm and aim to monitor senior managers and prevent any potential activities that may deviate from enhancing the value of the 
firm. However, the interest coordination between the senior managers and the shareholders is very hard to succeed due to the poor monitoring effectiveness of directors on the senior managers. Not only can the tasks' characteristics of the senior managers lower the monitoring effectiveness, but the potential collusion behavior among senior managers can undermine the monitoring effectiveness to an even greater extent.

As one of the functions of the board of directors is to ensure that the top managers give priority to the interests of the shareholders, the principal-agent theory has suggested that the board with a higher degree of gender diversity would monitor the CEO better, because the gender diversity increases the independence of the board (Carter et al., 2010) [3]. To be specific, the existence of women on the board reduces the possibility of collusive behavior among senior managers, and it further improves the supervision intensity of the board over senior managers (Adams, \&Ferreira, 2009) [4].

When it comes to the role of the women directors in setting the ESPD, it can be concluded as follows. Since the women directors are the better monitors than their male counterparts, they would intend to protect the interests of the shareholders by attempting to set an optimistic ESPD, which can motivate senior managers and frontline workers to work harder. According to the existing knowledge of the performance consequences of the ESPD, a larger ESPD would improve a firm's performance. Therefore, when the women directors can determine the decisionmaking issues to a better degree, they would set a relatively higher ESPD out of a higher firm-serving motivation than their male peers. Consequently, according to the view of the principal-agent theory, women directors would play a positive role in setting the ESPD.

Accordingly, from the perspective of the principal-agent theory, the paper has the following hypothesis:

H1: The women directors' participation has a positive effect on the ESPD.

\subsection{The Negative Role of the Women Directors Drawing the Human Capital Theory}

The human capital theory claims that the human capital exerts a stronger effect than the physical capital on the economic growth in the macro level and the firm development in the micro level. In the real world of business, the men dominate promotion decisions in the workplace. For the women, it is much harder to get the promotion opportunities than the men even if they hold the same qualifications. Under such a condition, women who want to become senior managers must have higher human capital than their male competitors. The research results of Smith and Verner (2006) have shown that the positive effects of women in top management strongly depend on the qualifications of women directors [5]. It is well accepted that the nature of the women's human capital would help senior managers to provide more innovative insights and ideas for running the companies (Zelechowski,
\&Bilimoria, 2004) [6]. Therefore, the human capital theory indicates that women directors have a positive role in determining the corporate performance by enhancing the level of total human capital and enriching the human capital structure of the directors.

When it comes to the role of the women directors in setting the ESPD, the human capital theory can also provide the additional good suggestions. According to the human capital theory, the human capital of women directors differs in quality and quantity from that of male directors, which would bring different knowledge contributions to corporate governance and business operating practices. When the board determines the ESPD, they would evaluate the value of the senior managers and estimate their contributions. Since the human capital of women directors contributes more to the decision-making process of senior managers, the overall performance or engagement evaluation results over the senior managers by the board would get lower and thus decrease the total compensation of executives. Therefore, all else equal, the gap between the senior managers' pay and the staff's salary would get smaller.

Accordingly, from the perspective of the human capital theory, the paper has the following hypothesis:

H2: The women directors' participation has a negative effect on the ESPD.

\section{METHOD}

\subsection{Sample}

Taking all the listed energy companies which existed during the period from 2010 to 2018 in the Shanghai stock exchange and the Shenzhen stock exchange as the initial sample framework, the paper selects the final research sample according to the following requirements: (1) The firms should be listed before 2009; (2) The firms should not be ever punished publicly by the government authorities for any reasons during the sampling years; (3) The firms should not be ever marked with ST, PT, SST, or *ST in the sampling year; (4) The firms should disclose all the data that the chapter needs according to the specific measures' design in this paper; (5) The firms should run relatively normally and smoothly. According to such rules, an unbalanced panel sample consisting of 1554 firm-year observations is designed.

\subsection{Measures}

The women directors' participation degree (WDPD): Referring to Torchia et al. (2011) [7], this study adopts the "ratio of the number of the women directors to the total size of the board" to measure WDPD.

The ESPD (ESPD): Referring to Zhang et al. (2018) [1], the ratio of "the average pay of the senior managers" to 
"the average pay of the front-line staff" is used to measure ESPD.

The control variables: Based on the literature review (Fang, 2019; Gilsoo Lee et al., 2019; Liu Ping et al., 2019) [8-10], seven variables which can affect the ESPD are selected as the control variables.

The firm size (FSIZE) is measured as the logarithm of the firm's total assets; The returns on assets (ROA) can represent the firm's performance; The executives' pay level(LNEP) is measured as the logarithm of the top three executives' average pay; The ratio of the senior managers' shareholdings(RTES) is measured as the ratio of the senior managers' shareholdings to the number of the total shares; The ratio of the first largest shareholding (RFLS) is measured as the ratio of the first largest shareholders' stock holdings to the number of the total shares; The independent directors ratio (IDR) is the ratio of the number of the independent directors to the board size; Debt ratio(DEBT) is the ratio of the debt to total assets.

Table 1. The descriptive statistics and correlation analysis results of the research variables ${ }^{\mathrm{a}}$

\begin{tabular}{|c|c|c|c|c|c|c|c|c|c|c|c|}
\hline Variables & Mean & Std. & WDPD & ESPD & FSIZE & ROA & LNEP & RTES & RFLS & IDR & DEBT \\
\hline WDPD & .112 & .104 & 1 & & & & & & & & \\
\hline ESPD & 6.224 & 6.493 & -.031 & 1 & & & & & & & \\
\hline FSIZE & 22.641 & 1.703 & $-.203^{* *}$ & .025 & 1 & & & & & & \\
\hline ROA & .0403 & .061 & $.058^{*}$ & $.070^{* *}$ & $-.106^{* *}$ & 1 & & & & & \\
\hline LNEP & 13.179 & .549 & -.023 & $.497^{* *}$ & $.398^{* *}$ & .015 & 1 & & & & \\
\hline RTES & .078 & .172 & $.216^{* *}$ & -.039 & $-.493^{* *}$ & $.192^{* *}$ & $-.151^{* *}$ & 1 & & & \\
\hline RFLS & 40.117 & 16.963 & $-.153^{* *}$ & $-.170^{* *}$ & $.424^{* *}$ & $.115^{* *}$ & $-.083^{* *}$ & $-.180^{* *}$ & 1 & & \\
\hline IDR & .372 & .052 & $.108^{* *}$ & -.037 & $-.092^{* *}$ & .007 & $-.053^{*}$ & $.131^{* *}$ & -.027 & 1 & \\
\hline DEBT & .468 & .211 & $-.127^{* *}$ & -.003 & $.510^{* *}$ & $-.355^{* *}$ & $.097^{* *}$ & $-.478^{* *}$ & $.057^{*}$ & $-.132^{* *}$ & 1 \\
\hline
\end{tabular}

\subsection{Data}

The descriptive statistics analysis and the correlation analysis results are shown in Table 1 . For the energy listed companies, the average ROA of is $4.03 \%$, the average value of the largest shareholder's shareholding ratio is 40.12 , the average ratio of the senior managers' shareholdings is $7.8 \%$, and the average debt ratio is $46.8 \%$. Most important is that the average proportion of the women directors is $11.2 \%$. The average ESPD is about 6.22, indicating the senior managers earn more than 6 times that of the front-line staff. In Table 1, ESPD has the significant correlations with most of the control variables. All the correlations are below 0.5. The two facts show that the design of the control variables is rather reasonable, and the potential risk of the multicollinearity in this study would be acceptable.

\section{RESULTS}

\subsection{Main Results}

In order to test $\mathrm{H} 1$ and $\mathrm{H} 2$, the study designs Model (1) which takes ESPD as the dependent variable, chooses WDPD as the independent variable, and selects FISZE, ROA, LNEP, RTES, RFLS, IDR and DEBT as the control variables.

$E S P D_{i t}=\alpha+\beta_{1} W_{D P D}+\beta_{2} \operatorname{CONTROLS}_{i t}+\beta_{3} \sum Y E A R+\varepsilon_{i t}$
The regression results are shown in Collum II of Table 2. Collum II indicates that the women directors' participation has a negative effect on the ESPD $(B=-$ $3.683, \mathrm{P}=0.000), \mathrm{H} 2$ was founded.

\subsection{Robustness Test}

In order to test the validity of the empirical results, the paper tries to do robustness tests using the following three methods.

First, "the number of the women directors" is used to measure WDPD in Model (1), and Model (1*) is built. Regression results of Model $\left(1^{*}\right)$ show that $\mathrm{H} 2$ still holds; Second, the ratio of "the top three executives' average pay" to "the average pay of the front-line staff" is used to measure ESPD in Model (1), and Model (1**) is built. Regression results of Model (1**) show that $\mathrm{H} 2$ still holds; Third, considering the special requirements of panel data's characteristics on statistical analysis software's functions, STATA 14.0 has been used instead of SPSS 23.0 for hypotheses tests. Keeping all the variables in Model (1) unchanged, the regression results based on fixed-effects are consistent with the expectations of $\mathrm{H} 2$. Considering the length limitation of the paper, the robustness test results of the latter two steps are not reported in detail, being available on request. 
Table 2. Empirical results ${ }^{b}$

\begin{tabular}{|c|c|c|c|c|c|c|}
\hline Model & Model 1 & Model 2 & Model 1 & Model 1 & Model 3 & Model 3 \\
\hline Sample & WHOLE & WHOLE & PRE_SRO & POST_SRO & L_WDPD & H_WDPD \\
\hline WDPD & $\begin{array}{c}-3.683^{* * *} \\
(-2.671)\end{array}$ & $\begin{array}{c}-4.461 * * \\
(-2.450)\end{array}$ & $\begin{array}{c}-5.017 * * \\
(-2.298)\end{array}$ & $\begin{array}{l}.509 \\
(.394)\end{array}$ & -- & -- \\
\hline SRO & -- & $\begin{array}{c}-4.701 * * * \\
(-7.083)\end{array}$ & -- & -- & -- & -- \\
\hline SRO*WDPD & -- & $\begin{array}{l}4.320^{*} \\
(1.651)\end{array}$ & -- & -- & -- & -- \\
\hline FSIZE & $\begin{array}{l}-.933 * * * \\
(-7.288) \\
\end{array}$ & $\begin{array}{c}-.812 * * * \\
(-6.472)\end{array}$ & $\begin{array}{c}-.882 * * * \\
(-4.667)\end{array}$ & $\begin{array}{c}-.819 * * * \\
(-6.164)\end{array}$ & $\begin{array}{c}-.759 * * * \\
(-4.655)\end{array}$ & $\begin{array}{c}-.933 * * * \\
(-4.264)\end{array}$ \\
\hline ROA & $\begin{array}{c}8.158 * * * \\
(3.302) \\
\end{array}$ & $\begin{array}{c}3.856 \\
(1.575) \\
\end{array}$ & $\begin{array}{l}2.424 \\
(.616) \\
\end{array}$ & $\begin{array}{l}5.947 * * \\
(2.520)\end{array}$ & $\begin{array}{l}5.986 * \\
(1.654) \\
\end{array}$ & $\begin{array}{l}6.163 * \\
(1.948) \\
\end{array}$ \\
\hline LNEP & $\begin{array}{c}6.781 * * * \\
(22.902) \\
\end{array}$ & $\begin{array}{c}7.251 * * * \\
(24.641)\end{array}$ & $\begin{array}{l}7.850 * * * \\
(17.281)\end{array}$ & $\begin{array}{c}6.465 * * * \\
(21.497)\end{array}$ & $\begin{array}{c}6.825 * * * \\
(17.149) \\
\end{array}$ & $\begin{array}{c}6.963 * * * \\
(16.361) \\
\end{array}$ \\
\hline RTES & $\begin{array}{c}-2.046^{* *} \\
(-2.078) \\
\end{array}$ & $\begin{array}{c}-1.358 \\
(-1.413) \\
\end{array}$ & $\begin{array}{l}-1.168 \\
(-.759)\end{array}$ & $\begin{array}{l}-1.723^{*} \\
(-1.849)\end{array}$ & $\begin{array}{c}-4.823 * * * \\
(-3.161) \\
\end{array}$ & $\begin{array}{c}.990 \\
(.774) \\
\end{array}$ \\
\hline RFLS & $\begin{array}{c}.019 * \\
(-1.912) \\
\end{array}$ & $\begin{array}{c}-.026 * * * \\
(-2.689) \\
\end{array}$ & $\begin{array}{l}.037 * * \\
(-2.553) \\
\end{array}$ & $\begin{array}{c}-.009 \\
(-.825) \\
\end{array}$ & $\begin{array}{c}-.038 * * * \\
(-2.671) \\
\end{array}$ & $\begin{array}{c}-.015 \\
(-1.105) \\
\end{array}$ \\
\hline IDR & $\begin{array}{l}-1.164 \\
(-.433) \\
\end{array}$ & $\begin{array}{c}-.272 \\
(-.104) \\
\end{array}$ & $\begin{array}{l}-2.318 \\
(-.562) \\
\end{array}$ & $\begin{array}{l}1.937 \\
(.749) \\
\end{array}$ & $\begin{array}{c}-5.532 \\
(-1.329) \\
\end{array}$ & $\begin{array}{l}5.584^{*} \\
(1.678) \\
\end{array}$ \\
\hline DEBT & $\begin{array}{l}1.872 * * \\
(2.147)\end{array}$ & $\begin{array}{c}.906 \\
(1.059) \\
\end{array}$ & $\begin{array}{c}-.288 \\
(-.221) \\
\end{array}$ & $\begin{array}{c}3.233 * * * \\
(3.582)\end{array}$ & $\begin{array}{c}-.386 \\
(-.332) \\
\end{array}$ & $\begin{array}{c}4.263 * * * \\
(3.276)\end{array}$ \\
\hline YEAR & YES & YES & YES & YES & YES & YES \\
\hline $\mathrm{F}$ & 81.515 & 46.305 & 30.051 & 54.163 & 30.166 & 23.556 \\
\hline $\mathrm{R}^{2}$ & .297 & .339 & .302 & .488 & .306 & .369 \\
\hline Adjusted $\mathrm{R}^{2}$ & .293 & .332 & .292 & .479 & .295 & .353 \\
\hline $\mathrm{N}$ & 1554 & 1554 & 916 & 638 & 975 & 579 \\
\hline Sig. & .000 & .000 & .000 & .000 & .000 & .000 \\
\hline
\end{tabular}

\subsection{Further Exploration}

\subsubsection{The effect of Salary Restriction Order on ESPD}

In 2015, the Chinese government issued a "Salary Restriction Order" in an attempt to control the excessive growth of the ESPD within enterprises. We want to explore how the Salary Restriction Order affects ESPD directly and changes the women directors' attitudes towards ESPD in practice. SRO is coded as 1 for the observations after 2015; otherwise, SRO is coded as zero. Model (2) is built to address this issue. The regression results are shown in Collum III of Table 2. Collum III indicates that the Salary Restriction Order has a direct negative effect on ESPD $(\mathrm{B}=-$ 4.701, $\mathrm{P}=0.000$ ), while shows a positive moderating effect on women directors' attitudes towards ESPD.

$$
\begin{aligned}
E S P D_{i t} & =\alpha+\beta_{1} W D P D_{i t}+\beta_{2} S R O+\beta_{3} S R O * W D P D \\
& +\beta_{4} C O N T R O L S_{i t}+\beta_{5} \sum Y E A R+\varepsilon_{i t}
\end{aligned}
$$

Besides, we set the observations before 2016 as the PRE_SOR sub-sample, while setting the observations after 2015 as the POST_SOR sub-sample. The regression results of Model (1) with the two sub-samples are respectively shown in Collum IV and Collum V of Table 2. It can be seen that before the issue of Salary Restriction Order, women directors show greater negative effects on ESPD; while after the issue of Salary Restriction Order, women directors show insignificant effects on ESPD. This empirical finding shows that there is a significant substitution effect between women directors' salary supervision and government salary regulation.

\subsubsection{The indirect effects of women directors on ESPD}

In order to explore how women directors can change the attitudes of other internal stakeholders towards ESPD, the whole sample is divided into H_WDPD sub-sample and L_WDPD sub-sample at the sample mean of WDPD (i.e., $\bar{W} D P D=0.112$ ). WDPD is removed from Model (1), and thus Model (3) is built. 
According to the study results reported in Collum VI and Collum VII of Table 2, the women directors would weaken the negative effect of senior managers shareholding on ESPD, reduce the negative attitudes of the first largest shareholders towards ESPD, inspire the positive attitudes of the independent directors towards ESPD, and most significantly, change the negative attitudes of the debtors towards ESPD into positive attitudes.

\section{CONCLUSION}

Since the causal patterns of the effect of women directors on the ESPD have not been clarified to an acceptable degree, this paper focuses on the role of the women directors' participation degree in setting the ESPD. The empirical results show that the women directors' participation degree is negatively with the ESPD in enterprises, indicating that the more discretion in the decision-making processes the women directors have, the lower ESPD would be.

Moreover, since there is a significant substitution effect between women directors' salary supervision and the governments' salary regulation, the negative effect of women directors on ESPD has been weakened into a nearly insignificant effect due to the issue of the Salary Restriction Order. Besides the reasons discussed in Section 2.2 why women directors favor narrower ESPD from the perspective of the Human capital Theory, another possible reason can be clarified as follows. Such a decrease in the ESPD derives from the higher workers' pay partly determined by the women directors due to their sympathy for the employees' life pressure and their needs for harmonious interpersonal atmosphere based on their gender nature.

\section{ACKNOWLEDGMENT}

This research was sponsored by the National Social Science Fund Project "Research On The Compensation Adjustment Effect Of Female Executives' Participation Degree In Corporate Governance And Its Performance Improvement Mechanism (20BGL147)".

\section{REFERENCES}

[1]C. Zhang, J. Zhang, Q. Guo, and X. Wei, "Effect of CEO-Worker Pay Ratio on Workplace Innovative Behavior: A Multipath Perspective," International Journal of Economics and Business Administration, vol. 4, issue. 3, 2018, pp. 93-104.

[2]D.C. Hambrick and P.A. Siegel, "Pay Dispersion within Top Management Groups: Harmful Effects on performance of High-Technology Firms," Academy of Management Proceedings, issue. 1, 1997, pp. 26-29. DOI: https://doi.org/10.5465/ambpp.1997.4978025

[3]D.A. Carter, F. D’Souza, B.J. Simkins, and W.G. Simpson, "The gender and ethnic diversity of US boards and board committees and firm financial performance," Corporate governance: An International Review, vol. 18, issue. 5, 2010, pp. 396434. DOI: https://doi.org/10.1111/j.14678683.2010.00809.x

[4]R. Adams and D. Ferreira, "Women in the boardro om and their impact on governance and performanc e," Journal of Financial Economics, vol. 94, issue. 2, 2009, pp. 291-309. DOI: https://doi.org/10.1016/j.jfin eco.2008.10.007

[5]N. Smith, V. Smith, and M. Verner, "Do women in top management affect firm performance? A panel study of 2,500 Danish firms," International Journal of Productivity and Performance Management, vol. 55, issue. 7, 2006, pp. 569-593. DOI: https://doi.org/10.1108/17410400610702160

[6]D.D. Zelechowski and D. Bilimoria, "Characteristics of women and men corporate in side directors in the US," Corporate Governance: An International Review, vol. 12, issue. 3, 2004, pp. 337 342. DOI: https://doi.org/10.1111/j.14678683.2004.00374.x

[7]M. Torchia, A. Calabrò, and M. Huse, "Women Directors on Corporate Boards: From Tokenism to Critical Mass,” Bus. Ethics, issue. 102, 2011, pp. 299317. DOI: https://doi.org/10.1007/s10551-011-0815-z

[8]S. Fang, "Homophily Exclusion or Homophily Preference? The Influence of the Executive Identity of Nonexecutive Directors on the Focal Firm Executive Pay and Ordinary Employee Pay," Journal of Systems Science and Information, vol. 7, issue. 6, 2019, pp. 550-567. DOI: 10.21078/JSSI-2019-550-18

[9]G. Lee and S.Y. Cho, "Jonathan Arthurs and Eun Kyung Lee. CEO pay inequity, CEO-TMT pay gap, and acquisition premiums," Journal of Business Research, vol. 98, issue. C, 2019, pp. 105-116. DOI: https://doi.org/10.1016/j.jbusres.2019.01.023

[10]L. Ping, H.M. Sajjad, and L. Liyan, "Does the compensation gap between executives and staffs influence future firm performance? The moderating roles of managerial power and overconfidence," International Journal of Management and Economics, vol. 55, issue. 4, 2019, pp. 287-318. DOI: https://doi.org/10.2478/ijme-2019-0025 